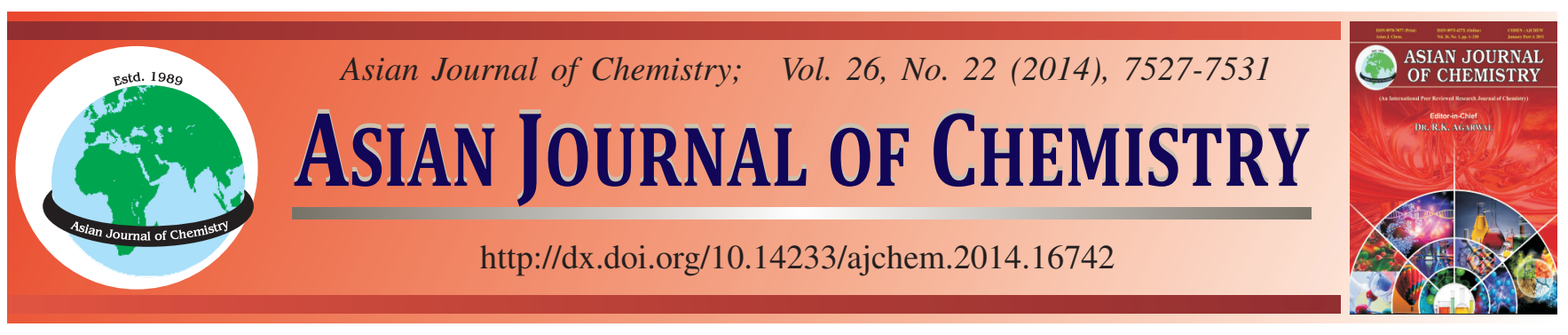

\title{
Direct Hydroxylation of $p$-Xylene to 2,5-Xylenol with Hydroxylamine in Ionic Liquids/Molybdenum Catalytic System
}

\author{
D. ZhANG ${ }^{*}$, L. GaO, C. Jin, W. Xue, X. ZhaO, S. WANG and Y. WAnG*
}

School of Chemical Engineering, Hebei University of Technology, Tianjin, P.R. China

*Corresponding authors: Fax: +86 22 60204061; Tel: +86 22 60200445; E-mail: zds1301@ hebut.edu.cn; yjwang@ hebut.edu.cn

Direct hydroxylation of $p$-xylene to 2,5-xylenol with hydroxylamine was carried out in an ionic liquids/molybdenum catalytic system. High 2,5-xylenol selectivity (80-98 \%) can be achieved with good $p$-xylene conversion (5.9-9.9\%) in this catalytic system. The recycling experiments suggested the ionic liquids/molybdenum catalytic system was stable enough to be recycled for the hydroxylation reaction.

Keywords: Ionic liquids, Molybdenum, $p$-Xylene, Hydroxylamine, Hydroxylation, 2,5-Xylenol.

\section{INTRODUCTION}

2,5-Xylenol is a valuable intermediate for the preparation of phenolic resins, dyes, antiseptics, etc ${ }^{1}$. It was originally extracted from coal tar and then synthesized by chlorination or sulfonation of $p$-xylene ${ }^{2}$. But there are some drawbacks with these synthetic processes, such as multistep procedures and harsh conditions ${ }^{3}$. In addition, vapor-phase alkylation of $m$-cresol with methanol is another way to produce 2,5-xylenoll ${ }^{4,5}$. However, it requires high costs for raw materials and product separation.

In recent years, one-step process has been realized for direct hydroxylation of $p$-xylene to 2,5-xylenol. And it has received considerable attention for its potential economic advantage and eco-efficiency. For example, Appelman et al. ${ }^{6}$ found that a reaction of $p$-xylene with hypofluorous acid leads to 2,5-xylenol. However, 2,5-xylenol selectivity was only 35.2 $\%$. Monfared et al. ${ }^{7}$ studied the liquid phase hydroxylation of p-xylene with $\mathrm{H}_{2} \mathrm{O}_{2}$. The reaction gave $54 \%$ 2,5-xylenol selectivity with $24 \%$-xylene conversion. In previous work ${ }^{8,9}$, phenols was synthesized from aromtatics and hydroxylamine in $\mathrm{H}_{2} \mathrm{SO}_{4}-\mathrm{CH}_{3} \mathrm{COOH}-\mathrm{H}_{2} \mathrm{O}$ medium. This process improved the selectivity towards 2,5-xylenol up to $70 \%$. But sulfuric acid was used as a solvent, which may cause equipment corrosion and environmental pollution.

Recently ionic liquids (ILs) have attracted much attention due to their unique properties, such as reusability and ecofriendliness ${ }^{10,11}$. And ionic liquids have been used as reaction media $^{12,13}$, or catalyst in chemical processes ${ }^{14,15}$. More recently, ionic liquids were successfully used as a co-solvent, in the reaction of direct hydroxylation of aromatics to phenols with hydroxylamine ${ }^{16}$. Interestingly, nearly $100 \%$ selectivity was achieved for 2,5-xylenol. However, the yield of 2,5-xylenol was only around $3 \%$ in the process.

To improve the yield of 2,5-xylenol, further study was carried out in the present work for $p$-xylene hydroxylation, using ionic liquids-containing media catalyzed by ammonium molybdate (Mo) catalyst (denoted as ILs/Mo catalytic system). A schematic representation of the reaction is given in SchemeI. Various reaction parameters such as temperature, time, the amount of hydroxylamine and catalyst were optimized. And higher yield of 2,5-xylenol were obtained in this study.

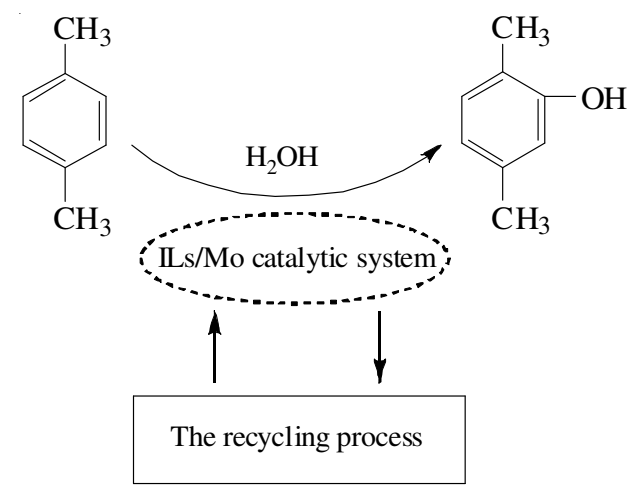

Scheme-I: Schematic representation of $p$-xylene hydroxylation process

\section{EXPERIMENTAL}

Preparation of ionic liquids: Ionic liquid $\left[\mathrm{HSO}_{3}\right.$-bmim] $\left[\mathrm{CF}_{3} \mathrm{SO}_{3}\right]$ was prepared as follows ${ }^{17,18}$ : equimolar N-methylimidazole and 1,4-butane sultone were charged into a $250 \mathrm{~mL}$ round-bottom flask and the mixture was stirred at $40{ }^{\circ} \mathrm{C}$ for 
$10 \mathrm{~h}$. The solid zwitterion $\left[\mathrm{HSO}_{3}\right.$-bmim] was washed with toluene and ethyl ether and dried in vacuum. Then a stoichiometric amount of trifluoromethane sulfonic acid was added to the $\left[\mathrm{HSO}_{3}\right.$-bmim] and stirred for $4 \mathrm{~h}$ at $80{ }^{\circ} \mathrm{C}$. The obtained viscous liquid was washed with ether and dried in vacuum to form $\left[\mathrm{HSO}_{3}\right.$-bmim $]\left[\mathrm{CF}_{3} \mathrm{SO}_{3}\right]$. Synthesis and purification of other ionic liquids were similar to that of the above procedure. The structures of the ionic liquids are given in Fig. 1.

$$
\mathrm{CH}_{3}-\overbrace{\mathrm{X}^{-}}^{\mathrm{N}} \mathrm{SO}_{3} \mathrm{H}
$$

$\left[\mathrm{HSO}_{3}\right.$-bmim] $\left[\mathrm{CF}_{3} \mathrm{SO}_{3}\right] ; \mathrm{X}=\mathrm{CF}_{3} \mathrm{SO}_{3}$ $\left[\mathrm{HSO}_{3}\right.$-bmim $]\left[\mathrm{H}_{2} \mathrm{PO}_{4}\right] ; \quad \mathrm{X}=\mathrm{H}_{2} \mathrm{PO}_{4}$<smiles></smiles>

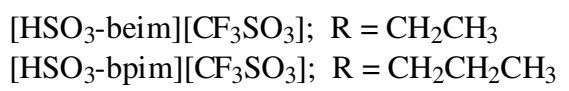<smiles>C[N+](C)(C)CCCCS(=O)(=O)O</smiles>

$\left[\mathrm{HSO}_{3}\right.$-btma $]\left[\mathrm{CF}_{3} \mathrm{SO}_{3}\right]$

Fig. 1. Ionic liquids used in this study

Determination of the Hammett acidity function of ionic liquids: The ionic liquids and the indicator 4-nitroaniline were dissolved in double distilled water at concentrations of $10 \times$ $10^{-3} \mathrm{~mol} / \mathrm{L}$ and $1.5 \times 10^{-4} \mathrm{~mol} / \mathrm{L}$, respectively. Then their UVvisible spectra were recorded on a Varian Cary 300 spectrophotometer at room temperature.

General procedure and detection method: The hydroxylation reaction was carried out in a $100 \mathrm{~mL}$ three-necked flask. Typically, hydroxylamine salts, catalyst and reaction media were charged into the flask. After stirring for about 15 min at $30{ }^{\circ} \mathrm{C}, p$-xylene was introduced and the reaction mixture was heated at $90{ }^{\circ} \mathrm{C}$ for $4 \mathrm{~h}$. The resulting mixture was cooled and neutralized to $\mathrm{pH}=6-8$ with a solution of sodium hydroxide. Then the obtained organic phase was extracted with ether and the concentrations of organic components were analyzed by a SP-3420 gas chromatography. $p$-xylene conversion ( $\left.\mathrm{X}_{\text {Xylene }}\right)$ and product selectivity $\left(\mathrm{S}_{\mathrm{i}}\right)$ were calculated by the following eqns. 1 and 2:

$$
\begin{gathered}
\mathrm{X}_{\text {Xylene }}=\left[1-\frac{8 \frac{\mathrm{W}_{\text {xylene }}}{\mathrm{M}_{\text {xylene }}}}{\sum\left(\mathrm{n}_{\mathrm{i}} \frac{\mathrm{W}_{\mathrm{i}}}{\mathrm{M}_{\mathrm{i}}}\right)}\right] \cdot 100 \% \\
\mathrm{~S}_{\mathrm{i}}=\frac{\left.\mathrm{n}_{\mathrm{i}} \frac{\mathrm{W}_{\mathrm{i}}}{\mathrm{M}_{\mathrm{i}}}\right] \cdot 100 \%}{\sum_{\mathrm{i} \neq \text { Xylene }}\left(\mathrm{n}_{\mathrm{i}} \frac{\mathrm{W}_{\mathrm{i}}}{\mathrm{M}_{\mathrm{i}}}\right)}
\end{gathered}
$$

where $n_{i}$ is the number of carbon atoms in each molecule of $i$ component, $\mathrm{W}_{\mathrm{i}}$ is the weight percentage of $\mathrm{i}$ component and $\mathrm{M}_{\mathrm{i}}$ is the molar mass of $\mathrm{i}$ component.

For recycling of the ILs/Mo catalytic system, the same procedure was used as mentioned above. However, when the hydroxylation was stopped, the reaction mixture was cooled and extracted directly with ether without neutralization process. All the organic compounds including $p$-xylene, 2,5-xylenol and acetic acid, could be entirely extracted by ether for further analysis. The obtained aqueous mixture was evaporated in a rotating vacuum evaporator to remove water. Then the recovered ILs/Mo catalytic system with the addition of acetic acid and water, was used again for testing.

\section{RESULTS AND DISCUSSION}

Determination of ionic liquid acidity: Considering aqueous acidic media is favorable for the present hydroxylation ${ }^{8,9}$, several $\mathrm{SO}_{3} \mathrm{H}$-functionalized ionic liquids were prepared as shown in Fig. 1. These ionic liquids are fully miscible in water and able to carry an acidic group $\left(-\mathrm{SO}_{3} \mathrm{H}\right)$. The acidity of the ionic liquids was evaluated from the determination of Hammett acidity functions, using UV-visible spectroscopy with 4-nitroanline as indicator in water ${ }^{19,20}$. As shown in Fig. 2, the maximum absorbance of the blank solution (unprotonated form of 4-nitroanline) is observed at $380 \mathrm{~nm}$, which decreased with addition of acidic ionic liquids. The decreasing order of the absorbance is observed as following: $\left[\mathrm{HSO}_{3}\right.$-bmim] $\left[\mathrm{H}_{2} \mathrm{PO}_{4}\right]$ $>\left[\mathrm{HSO}_{3}\right.$-bpim $]\left[\mathrm{CF}_{3} \mathrm{SO}_{3}\right]>\left[\mathrm{HSO}_{3}\right.$-beim $]\left[\mathrm{CF}_{3} \mathrm{SO}_{3}\right]>\left[\mathrm{HSO}_{3}-\right.$ bmim $]\left[\mathrm{CF}_{3} \mathrm{SO}_{3}\right]>\left[\mathrm{HSO}_{3}\right.$-btma $]\left[\mathrm{CF}_{3} \mathrm{SO}_{3}\right]$, which indicates that the acidity order of these ionic liquids to be adverse. Obviously, the acidity depends both on the nature of the cation and anion. The acidity of the ionic liquids with the anions $\left[\mathrm{CF}_{3} \mathrm{SO}_{3}\right]-$ is stronger than that with the $\left[\mathrm{H}_{2} \mathrm{PO}_{4}\right]-$ anion. For imidazoliumbased ionic liquids $\left[\mathrm{HSO}_{3}\right.$-bpim $]\left[\mathrm{CF}_{3} \mathrm{SO}_{3}\right],\left[\mathrm{HSO}_{3}\right.$-beim $]\left[\mathrm{CF}_{3} \mathrm{SO}_{3}\right]$ and $\left[\mathrm{HSO}_{3}\right.$-bmim] $\left[\mathrm{CF}_{3} \mathrm{SO}_{3}\right]$, cations with a longer alkyl side chain cause a decrease in acidity.

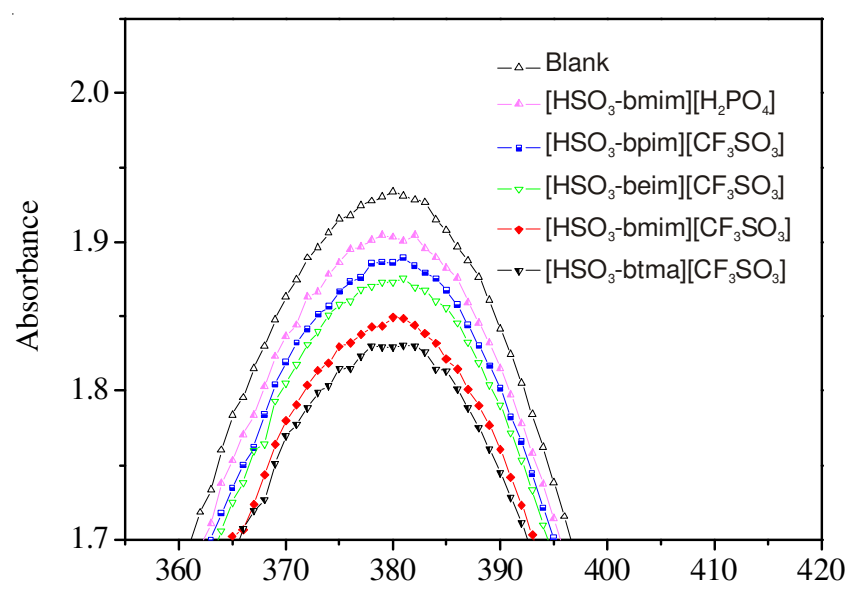

Fig. 2. Absorption spectra of 4-nitroaniline for various acidic ionic liquids in $\mathrm{H}_{2} \mathrm{O}$

Selection of a suitable ILs/Mo catalytic system: A series of solvents containing ionic liquids were tried for direct hydroxylation of $p$-xylene. The results are listed in Tables 1 and 2. Initially the reaction was carried out in pure ionic liquid 
TABLE-1

EFFECT OF REACTION MEDIUM ON THE CATALYTIC HYDROXYLATION OF $p$-XYLENE

\begin{tabular}{|c|c|c|c|c|}
\hline \multirow{2}{*}{ Entry } & \multirow{2}{*}{ Reaction media (g:g:g ) } & \multirow{2}{*}{$\mathrm{X}_{\text {Xylene }}(\%)$} & \multicolumn{2}{|c|}{$\mathrm{S}_{\mathrm{i}}(\%)$} \\
\hline & & & 2,5-xylenol & Others ${ }^{\mathrm{a}}$ \\
\hline 1 & {$\left[\mathrm{HSO}_{3}-\right.$ bmim $]\left[\mathrm{CF}_{3} \mathrm{SO}_{3}\right](12 \mathrm{~g})$} & 0 & - & - \\
\hline 2 & {$\left[\mathrm{HSO}_{3}-\mathrm{bmim}\right]\left[\mathrm{CF}_{3} \mathrm{SO}_{3}\right]-\mathrm{H}_{2} \mathrm{O}(6: 8)$} & 0.3 & 37.2 & 62.8 \\
\hline 3 & {$\left[\mathrm{HSO}_{3}-\right.$ bmim $]\left[\mathrm{CF}_{3} \mathrm{SO}_{3}\right]-\mathrm{CH}_{3} \mathrm{COOH}-\mathrm{H}_{2} \mathrm{O}(2: 10: 4)$} & 3.1 & 93.7 & 6.3 \\
\hline 4 & {$\left[\mathrm{HSO}_{3}-\mathrm{bmim}\right]\left[\mathrm{CF}_{3} \mathrm{SO}_{3}\right]-\mathrm{CH}_{3} \mathrm{COOH}-\mathrm{H}_{2} \mathrm{O}(3: 10: 4)$} & 3.6 & 93.8 & 6.2 \\
\hline 5 & {$\left[\mathrm{HSO}_{3}-\mathrm{bmim}\right]\left[\mathrm{CF}_{3} \mathrm{SO}_{3}\right]-\mathrm{CH}_{3} \mathrm{COOH}-\mathrm{H}_{2} \mathrm{O}(4: 10: 4)$} & 5.9 & 98.3 & 1.7 \\
\hline 6 & {$\left[\mathrm{HSO}_{3}-\mathrm{bmim}\right]\left[\mathrm{CF}_{3} \mathrm{SO}_{3}\right]-\mathrm{CH}_{3} \mathrm{COOH}-\mathrm{H}_{2} \mathrm{O}(5: 10: 4)$} & 6.4 & 88.4 & 11.6 \\
\hline 7 & {$\left[\mathrm{HSO}_{3}\right.$-bmim $]\left[\mathrm{CF}_{3} \mathrm{SO}_{3}\right]-\mathrm{CH}_{3} \mathrm{COOH}-\mathrm{H}_{2} \mathrm{O}(6: 10: 4)$} & 8.2 & 90.6 & 9.4 \\
\hline
\end{tabular}

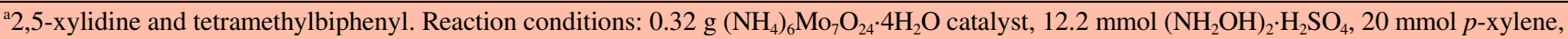
$90^{\circ} \mathrm{C}, 4 \mathrm{~h}$

TABLE-2

EFFECT OF THE KIND OF IONIC LIQUIDS ON THE CATALYTIC HYDROXYLATION OF $p$-XYLENE

\begin{tabular}{|c|c|c|c|c|}
\hline \multirow{2}{*}{ Entry } & \multirow{2}{*}{ Reaction media $^{\mathrm{a}}$} & \multirow{2}{*}{$\mathrm{X}_{\text {Xylene }}(\%)$} & \multicolumn{2}{|c|}{$\mathrm{S}_{\mathrm{i}}(\%)$} \\
\hline & & & 2,5-xylenol & Others $^{\mathrm{b}}$ \\
\hline 8 & {$\left[\mathrm{HSO}_{3}-\mathrm{bmim}\right]\left[\mathrm{H}_{2} \mathrm{PO}_{4}\right]-\mathrm{CH}_{3} \mathrm{COOH}-\mathrm{H}_{2} \mathrm{O}$} & 1.7 & 91.6 & 8.4 \\
\hline 9 & {$\left[\mathrm{HSO}_{3}-\mathrm{bpim}\right]\left[\mathrm{CF}_{3} \mathrm{SO}_{3}\right]-\mathrm{CH}_{3} \mathrm{COOH}-\mathrm{H}_{2} \mathrm{O}$} & 3.2 & 92.0 & 8.0 \\
\hline 10 & {$\left[\mathrm{HSO}_{3}\right.$-beim $]\left[\mathrm{CF}_{3} \mathrm{SO}_{3}\right]-\mathrm{CH}_{3} \mathrm{COOH}-\mathrm{H}_{2} \mathrm{O}$} & 4.4 & 93.2 & 6.8 \\
\hline 11 & {$\left[\mathrm{HSO}_{3}\right.$-bmim $]\left[\mathrm{CF}_{3} \mathrm{SO}_{3}\right]-\mathrm{CH}_{3} \mathrm{COOH}-\mathrm{H}_{2} \mathrm{O}$} & 5.9 & 98.3 & 1.7 \\
\hline 12 & {$\left[\mathrm{HSO}_{3}\right.$-btma $]\left[\mathrm{CF}_{3} \mathrm{SO}_{3}\right]-\mathrm{CH}_{3} \mathrm{COOH}-\mathrm{H}_{2} \mathrm{O}$} & 4.9 & 88.3 & 11.7 \\
\hline
\end{tabular}

$\left[\mathrm{HSO}_{3}\right.$-bmim] $\left[\mathrm{CF}_{3} \mathrm{SO}_{3}\right]$ (Table-1). But no reaction is observed. And pure ionic liquids did not give complete dissolution of hydroxylamine sulfate. Considering hydroxylamine salts is entirely soluble in water, $\left[\mathrm{HSO}_{3}-\mathrm{bmim}\right]\left[\mathrm{CF}_{3} \mathrm{SO}_{3}\right]-\mathrm{H}_{2} \mathrm{O}$ solution was used as reaction media. However, the conversion of $p$-xylene is nearly zero $(0.3 \%)$, revealing no activity of the Mo catalyst in this aqueous solution.

Previous studies showed that $\mathrm{H}_{2} \mathrm{SO}_{4}-\mathrm{CH}_{3} \mathrm{COOH}-\mathrm{H}_{2} \mathrm{O}$ medium with a weight ratio of 2:10:4 is favorable for the hydroxylation ${ }^{9}$. Consequently, a weight ratio of 2:10:4 $\left[\mathrm{HSO}_{3}-\right.$ bmim] $\left[\mathrm{CF}_{3} \mathrm{SO}_{3}\right]-\mathrm{CH}_{3} \mathrm{COOH}-\mathrm{H}_{2} \mathrm{O}$ solution was used as a reaction media (Entry 3). Fortunately, the desired reaction can be achieved. And $p$-xylene conversion increases to $3.1 \%$ with $93.7 \%$ selectivity for 2,5-xylenol. Hence subsequent studies were conducted in various $\left[\mathrm{HSO}_{3}-\mathrm{bmim}\right]\left[\mathrm{CF}_{3} \mathrm{SO}_{3}\right]-$ $\mathrm{CH}_{3} \mathrm{COOH}-\mathrm{H}_{2} \mathrm{O}$ solvents containing different amount of ionic liquids. With increasing ionic liquids content, $p$-xylene conversion increases steadily. While 2,5-xylenol selectivity increases first and then decreases. Better result is obtained at a [ $\mathrm{HSO}_{3}$-bmim] $\left[\mathrm{CF}_{3} \mathrm{SO}_{3}\right]: \mathrm{CH}_{3} \mathrm{COOH}: \mathrm{H}_{2} \mathrm{O}$ weight ratio of $4: 10: 4$. The conversion of $p$-xylene and the selectivity for 2,5xylenol are 5.9 and $98.3 \%$, respectively.

To further investigate the effect of ionic liquids, several kinds of ionic liquids were selected to form acidic medium, while the weight ratio of ILs: $\mathrm{CH}_{3} \mathrm{COOH}: \mathrm{H}_{2} \mathrm{O}$ was keep at 4:10:4. Table- 2 gives the results. Interestingly, $p$-xylene conversion and 2,5-xylenol selectivity increase first and then decrease with increase the acidity of the ionic liquids. A small amount of 2,5-xylenol is obtained in $\left[\mathrm{HSO}_{3}\right.$-bmim] $\left[\mathrm{H}_{2} \mathrm{PO}_{4}\right]-$ $\mathrm{CH}_{3} \mathrm{COOH}-\mathrm{H}_{2} \mathrm{O}$ solvent, probably due to the weak acidity of $\left[\mathrm{HSO}_{3}\right.$-bmim $]\left[\mathrm{H}_{2} \mathrm{PO}_{4}\right]$ as demonstrated by UV-visible spectroscopy. Subsequently an increase in $p$-xylene conversion as well as 2,5-xylenol selectivity, is observed as the hydroxylation was performed in the following solutions, $\left[\mathrm{HSO}_{3}\right.$-bpim $]\left[\mathrm{CF}_{3} \mathrm{SO}_{3}\right]-$ $\mathrm{CH}_{3} \mathrm{COOH}-\mathrm{H}_{2} \mathrm{O},\left[\mathrm{HSO}_{3}\right.$-beim $]\left[\mathrm{CF}_{3} \mathrm{SO}_{3}\right]-\mathrm{CH}_{3} \mathrm{COOH}-\mathrm{H}_{2} \mathrm{O}$ and
$\left[\mathrm{HSO}_{3}\right.$-bmim $]\left[\mathrm{CF}_{3} \mathrm{SO}_{3}\right]-\mathrm{CH}_{3} \mathrm{COOH}-\mathrm{H}_{2} \mathrm{O}$. Better result is observed in $\left[\mathrm{HSO}_{3}\right.$-bmim $]\left[\mathrm{CF}_{3} \mathrm{SO}_{3}\right]-\mathrm{CH}_{3} \mathrm{COOH}-\mathrm{H}_{2} \mathrm{O}$ solvent system. Therefore, the $\left[\mathrm{HSO}_{3}-\mathrm{bmim}\right]\left[\mathrm{CF}_{3} \mathrm{SO}_{3}\right]-\mathrm{CH}_{3} \mathrm{COOH}-\mathrm{H}_{2} \mathrm{O}$ solution with a weight ratio of $4: 10: 4$ was chosen as a reaction media. Then an ionic liquids/molybdenum catalytic system, i.e., combination of the above media with $\left(\mathrm{NH}_{4}\right)_{6} \mathrm{Mo}_{7} \mathrm{O}_{24} \cdot 4 \mathrm{H}_{2} \mathrm{O}$ catalyst, was selected as the ILs/Mo catalytic system.

Optimization of reaction conditions: As the above ILs/ Mo catalytic system showed better activity, the catalytic system was selected for further investigation. Figs. 3 and 4 display the effect of reaction temperature and time on $p$-xylene hydroxylation. With the temperature rise from 50 to $95^{\circ} \mathrm{C}, p$ xylene conversion as well as 2,5-xylenol selectivity increases first, passing through a maximum at $90{ }^{\circ} \mathrm{C}$ and then decreases. Among the reaction time, higher conversion of $p$-xylene can be obtained by prolonging reaction time. However, $p$-xylene conversion increases slightly when the time exceeded $4 \mathrm{~h}$. Therefore, the optimum reaction temperature and time are $90{ }^{\circ} \mathrm{C}$ and $4 \mathrm{~h}$, respectively.

Various amounts of Mo catalyst and hydroxylamine were also examined. The results are showed in Figs. 5 and 6. With increasing catalyst dosage, the selectivity of 2,5-xylenol increases steadily and then keep around $96 \%$. For $p$-xylene conversion, a bell-shaped dependence on catalyst amount is observed. High yield of 2,5-xylenol is obtained at 0.2-0.5 $\mathrm{g}$ of catalyst and the molar ratio of Mo to $p$-xylene is 1:7-18. As for the influence of hydroxylamine, $p$-xylene conversion increases steadily from 1 to $9.9 \%$ with the variation of hydroxylamine dose from 0.8 to $4.9 \mathrm{~g}$. However, 2,5-xylenol selectivity first keep around at $98 \%$ and then decreases to $80 \%$. Better results

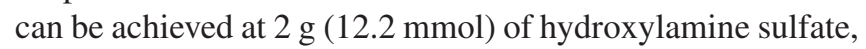
i.e. the molar ratio of $\mathrm{NH}_{2} \mathrm{OH}$ to $p$-xylene is $1.2: 1$.

Reusability of the ILs/Mo catalytic system: To investigate the possibility of reusing the ILs/Mo catalytic system, a series of recycle experiments were conducted. And the results 


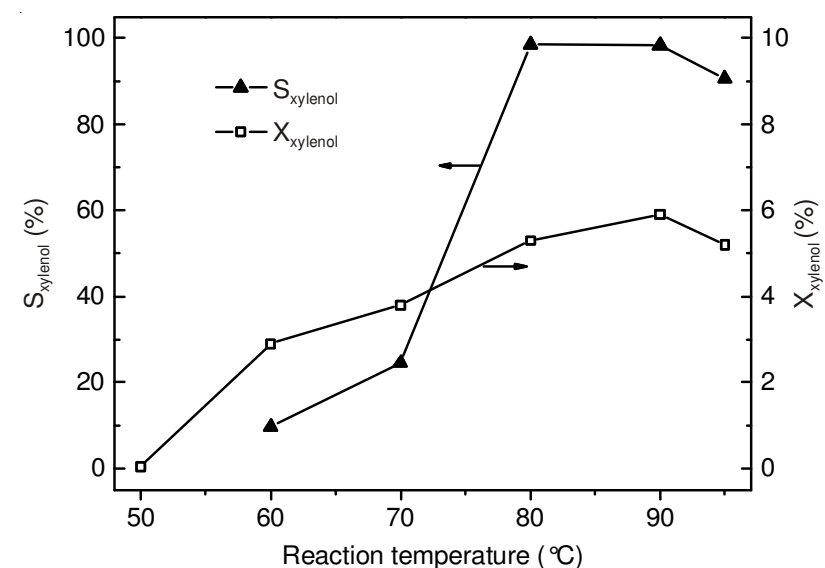

Fig. 3. Effect of reaction temperature on hydroxylation of $p$-xylene Reaction conditions: $0.32 \mathrm{~g}\left(\mathrm{NH}_{4}\right)_{6} \mathrm{Mo}_{7} \mathrm{O}_{24} \cdot 4 \mathrm{H}_{2} \mathrm{O}$ catalyst, 12.2 mmol $\left(\mathrm{NH}_{2} \mathrm{OH}\right)_{2} \cdot \mathrm{H}_{2} \mathrm{SO}_{4}, 20 \mathrm{mmol} p$-xylene, $18 \mathrm{~g}$ [ $\mathrm{HSO}_{3}$-bmim] $\left[\mathrm{CF}_{3} \mathrm{SO}_{3}\right]-\mathrm{CH}_{3} \mathrm{COOH}-\mathrm{H}_{2} \mathrm{O}$ media (the weight ratio is $\left.4: 10: 4\right), 4 \mathrm{~h}$

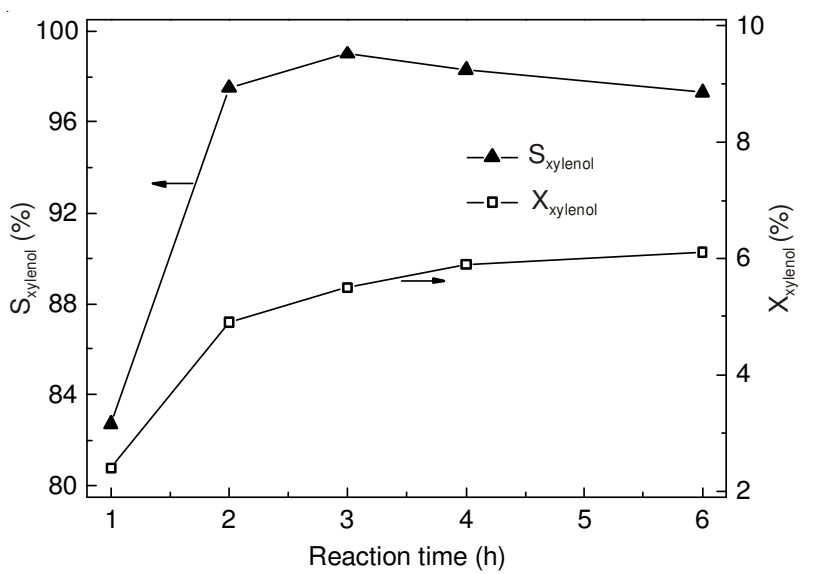

Fig. 4. Effect of reaction time on hydroxylation of $p$-xylene. Reaction conditions: $0.32 \mathrm{~g}\left(\mathrm{NH}_{4}\right)_{6} \mathrm{Mo}_{7} \mathrm{O}_{24} \cdot 4 \mathrm{H}_{2} \mathrm{O}$ catalyst, $12.2 \mathrm{mmol}$ $\left(\mathrm{NH}_{2} \mathrm{OH}\right)_{2} \cdot \mathrm{H}_{2} \mathrm{SO}_{4}, 20 \mathrm{mmol} p$-xylene, $18 \mathrm{~g}\left[\mathrm{HSO}_{3}-\mathrm{bmim}\right]\left[\mathrm{CF}_{3} \mathrm{SO}_{3}\right]-$ $\mathrm{CH}_{3} \mathrm{COOH}-\mathrm{H}_{2} \mathrm{O}$ media (the weight ratio is $4: 10: 4$ ), $90{ }^{\circ} \mathrm{C}$

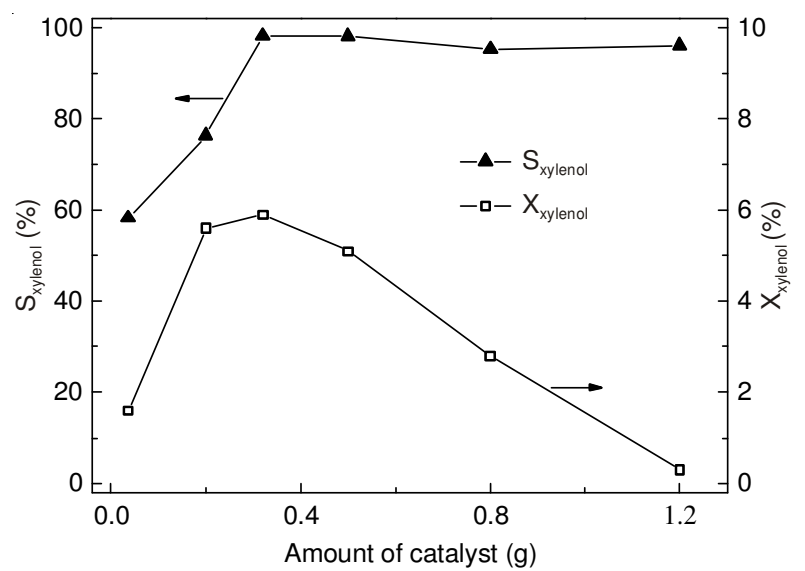

Fig. 5. Effect of the amount of catalyst on the hydroxylation reaction. Reaction conditions: $\left(\mathrm{NH}_{4}\right)_{6} \mathrm{Mo}_{7} \mathrm{O}_{24} \cdot 4 \mathrm{H}_{2} \mathrm{O}$ catalyst, $12.2 \mathrm{mmol}$ $\left(\mathrm{NH}_{2} \mathrm{OH}\right)_{2} \cdot \mathrm{H}_{2} \mathrm{SO}_{4}, 20 \mathrm{mmol} p$-xylene, $18 \mathrm{~g}\left[\mathrm{HSO}_{3}\right.$-bmim $]\left[\mathrm{CF}_{3} \mathrm{SO}_{3}\right]-$ $\mathrm{CH}_{3} \mathrm{COOH}-\mathrm{H}_{2} \mathrm{O}$ media (the weight ratio is $4: 10: 4$ ), $90{ }^{\circ} \mathrm{C}, 4 \mathrm{~h}$

are given in Table-3. There is nearly no decrease in $p$-xylene conversion after the catalytic system was reused for several times. It indicates that the ILs/Mo catalytic system was stable enough to be recycled for the hydroxylation. And more work will be performed in the near future.

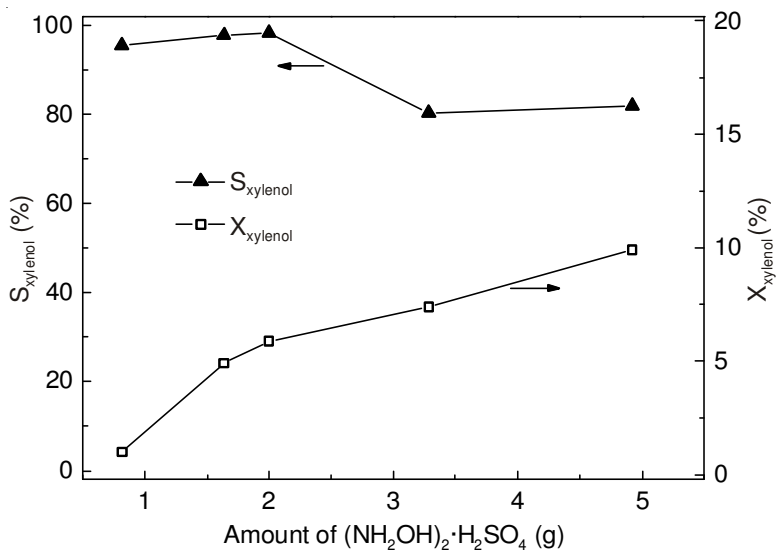

Fig. 6. Effect of the amount of hydroxylamine sulfate on the hydroxylation reaction. Reaction conditions: $0.32 \mathrm{~g}$ $\left(\mathrm{NH}_{4}\right)_{6} \mathrm{Mo}_{7} \mathrm{O}_{24} \cdot 4 \mathrm{H}_{2} \mathrm{O}$ catalyst, $20 \mathrm{mmol} p$-xylene, $18 \mathrm{~g}\left[\mathrm{HSO}_{3}-\right.$ bmim $]\left[\mathrm{CF}_{3} \mathrm{SO}_{3}\right]-\mathrm{CH}_{3} \mathrm{COOH}-\mathrm{H}_{2} \mathrm{O}$ media (the weight ratio is 4:10:4), $90{ }^{\circ} \mathrm{C}, 4 \mathrm{~h}$

\begin{tabular}{|c|c|c|c|}
\hline \multicolumn{4}{|c|}{$\begin{array}{c}\text { TABLE-3 } \\
\text { REUSE OF THE IONIC LIQUIDS/MO CATALYTIC } \\
\text { SYSTEM IN } p \text {-XYLENE HYDROXYLATION }\end{array}$} \\
\hline \multirow{2}{*}{ Run } & \multirow{2}{*}{$\mathrm{X}_{\text {Xylene }}(\%)$} & $\mathrm{S}_{\mathrm{i}}(\%)$ & \\
\hline & & 2,5-xylenol & Others $^{\mathrm{a}}$ \\
\hline 1 & 5.8 & 98.4 & 1.6 \\
\hline 2 & 6.2 & 98.1 & 1.9 \\
\hline 3 & 5.3 & 99.3 & 0.7 \\
\hline \multicolumn{4}{|c|}{$\begin{array}{l}\text { 2,5-xylidine and tetramethylbiphenyl. Reaction conditions: } 0.32 \mathrm{~g} \\
\left(\mathrm{NH}_{4}\right)_{6} \mathrm{Mo}_{7} \mathrm{O}_{24} \cdot 4 \mathrm{H}_{2} \mathrm{O} \text { catalyst, } 12.2 \mathrm{mmol}\left(\mathrm{NH}_{2} \mathrm{OH}\right)_{2} \cdot \mathrm{H}_{2} \mathrm{SO}_{4}, 20 \mathrm{mmol} \\
p \text {-xylene, } 18 \mathrm{~g}\left[\mathrm{HSO}_{3} \text {-bmim }\right]\left[\mathrm{CF}_{3} \mathrm{SO}_{3}\right]-\mathrm{CH}_{3} \mathrm{COOH}-\mathrm{H}_{2} \mathrm{O} \text { media (the } \\
\text { weight ratio is } 4: 10: 4), 90^{\circ} \mathrm{C}, 4 \mathrm{~h}\end{array}$} \\
\hline
\end{tabular}

\section{Conclusion}

In this paper, the $\left[\mathrm{HSO}_{3}\right.$-bmim $]\left[\mathrm{CF}_{3} \mathrm{SO}_{3}\right]-\mathrm{CH}_{3} \mathrm{COOH}-\mathrm{H}_{2} \mathrm{O}$ solution with a weight ratio of 4:10:4 was chosen as a better reaction media for direct hydroxylation of $p$-xylene with hydroxylamine. Then an ILs/Mo catalytic system, i.e., combination of the above media with $\left(\mathrm{NH}_{4}\right)_{6} \mathrm{Mo}_{7} \mathrm{O}_{24} \cdot 4 \mathrm{H}_{2} \mathrm{O}$ catalyst, was designed for the hydroxylation reaction. The optimized reaction conditions investigated were $\mathrm{Mo} / p$-xylene (molar ratio) $1: 7-18, \mathrm{NH}_{2} \mathrm{OH} / p$-xylene (molar ratio) 1.2:1, conducted at $90{ }^{\circ} \mathrm{C}$ for $4 \mathrm{~h}$. High 2,5-xylenol selectivity (80-98\%) and good $p$-xylene conversion (5.9-9.9\%) were achieved in the present catalytic system. Moreover, recycling experiments revealed that the ILs/Mo catalytic system was stable enough to be recycled for the hydroxylation.

\section{ACKNOWLEDGEMENTS}

The authors are grateful for the financial support of the National Natural Science Foundation of China (21236001, 21106029 and 21176056), National Natural Science Foundation of Tianjin (12JCQNJC03000) and National Natural Science Foundation of Hebei Province (B2012202043).

\section{REFERENCES}

1. P. Diévart, L. Allou, F. Louis, S. Le and Calvé, Phys. Chem. Chem. Phys., 8, 1714 (2006).

2. M. Weber and M. Weber, in ed.: L. Pilato, Phenolic Resins: A Century of Progress, Springer-Verlag: Berlin Heidelberg, Germany, Chap. 2, p. 9 (2010). 
3. B. Vogel, E. Klemm, M. Seitz, J. Heller and J. Reiser, US Patent 6476277B2 (2002)

4. V. Crocellà, G. Cerrato, G. Magnacca, C. Morterra, F. Cavani, S. Cocchi, S. Passeri, D. Scagliarini, C. Flego and C. Perego, J. Catal. 270, 125 (2010).

5. M. Bolognini, F. Cavani, D. Scagliarini, C. Flego, C. Perego and M. Saba, Catal. Today, 75, 103 (2002).

6. E.H. Appelman, R. Bonnett and B. Mateen, Tetrahedron, 33, 2119 (1977).

7. H.H. Monfared and Z.H. Amouei, J. Mol. Catal. Chem., 217, 161 (2004).

8. D. Zhang, L. Gao, Y. Wang, W. Xue, X. Zhao and S. Wang, Catal. Commun., 12, 1109 (2011).

9. D. Zhang, L. Gao, W. Xue, X. Zhao, S. Wang and Y. Wang, Chem. Lett., 41, 369 (2012).

10. W. Liu, L. Cheng, Y. Zhang, H. Wang and M. Yu, J. Mol. Liq., 140, 68 (2008).

11. P. Kubisa, Prog. Polym. Sci., 34, 1333 (2009).
12. F. Guo, Z. Fang, X.F. Tian, Y.D. Long and L.Q. Jiang, Bioresour. Technol., 102, 6469 (2011).

13. P.A. Ganeshpure, G. George and J. Das, J. Mol. Catal. Chem., 279, 182 (2008)

14. Y.W. Zhao, J.X. Long, F.G. Deng, X.F. Liu, Z. Li, C.G. Xia and J.J. Peng, Catal. Commun., 10, 732 (2009).

15. J. Gui, H. Ban, X. Cong, X. Zhang, Z. Hu and Z. Sun, J. Mol. Catal. Chem., 225, 27 (2005).

16. L. Gao, X. Tan, W. Xue, D. Zhang, X. Zhao and Y. Wang, Adv. Mater. Res., 781-784, 163 (2013).

17. Z. Duan, Y. Gu, J. Zhang, L. Zhu and Y. Deng, J. Mol. Catal. Chem., 250, 163 (2006).

18. J. Gui, X. Cong, D. Liu, X. Zhang, Z. Hu and Z. Sun, Catal. Commun., 5, 473 (2004).

19. C. Thomazeau, H. Olivier-Bourbigou, L. Magna, S. Luts and B. Gilbert, J. Am. Chem. Soc., 125, 5264 (2003).

20. X. Liu, H. Ma, Y. Wu, C. Wang, M. Yang, P. Yan and U. Welz-Biermann, Green Chem., 13, 697 (2011). 